South Asian J. Food Technol. Environ., 5(2): 864-873 (2019)

ISSN 2394-5168 (Print), 2454- 6445(online)

www.sweft.in

\title{
Quality evaluation of blended edible oils
}

\author{
Ratnesh Kumar*, Suresh Chandra, Samsher, Vikrant Kumar, Sunil and Pinkoo Singh \\ Deptt. of Agricultural Engineering, SVPUAT, Meerut (UP) \\ *Email: rkindian563@gmail.com
}

\begin{abstract}
The effect of storage conditions on the quality of mustard, soybean, sunflower and groundnut oils were analysed under storage upto 210 days in Room temperature, BOD incubator and Refrigerated condition. The mustard oil used as based oil for replacement. The mustard oil was replaced by (40-85), soybean, sunflower and groundnut are each (5-20\%). During the storage of individual and blended oil, pH was increase with increasing the storage period and types of storage condition. Density, specific gravity and iodine value was reduced with raising the storage period. Free fatty acid and peroxide value was increase with increasing the storage period and types of storage condition. Vegetable oils have wide application in foods where they are used in frying, cooking etc. Vegetable oils are produced from plant seeds, commonly used for frying, baking and other types of cooking. Edible oils and fats are biological mixtures.
\end{abstract}

Keyword: Crude oil, peroxide value, iodine value, $\mathrm{pH}$, room temperature

Paper cited: Kumar, R., Chandra, S., Samsher; Kumar, V., Sunil and Singh, P. (2019). Quality evaluation of blended edible oils. South Asian Journal of Food Technology and Environment, 5(2): 864873.

\section{Introduction}

They contain essential fatty acids which play an important role in nutrition and are also carriers of fat soluble vitamins. It is estimated that about $90 \%$ of vegetable oils are used for edible purposes, while the remaining part finds industrial applications. Fats and oils are one of the five essential ingredients of human diet and the others are protein, carbohydrates, minerals and vitamins (Shukla et al., 1992). The oil seeds are major source of edible in world. Vegetable oils are extremely damaging to the reproductive system and the developing bodies of unborn babies and children. Because the reproductive system in both men and women is constantly producing and dividing new cells, there is potential for mutation and problems when these cells are made of the wrong kind of fats and are oxidized. Because vegetable oils oxidize easily, they deplete the body of antioxidants since the body must use these to attempt to neutralize the oxidation. People with high consumption of vegetable oils and their products are at risk for Vitamin E deficiency and other deficiencies. Rapeseed (Brassica napus L.) is now the second most important source of vegetable oil in the world. Canola oil is also considered healthy for human nutrition due to its lowest content of saturated fatty acids among vegetable oils and moderate content of polyunsaturated fatty acids (Stamer et al., 1999). Mustard oil, used as traditional edible oil in most parts of India for centuries, is well known for its medicinal utilities (Rastogi et al., 2004; Dasgupta and Bhattacharyya, 2007). Brassica juncea L. is also known as Indian mustard or mustard greens or leaf mustard, is perennial herb, usually grown as annual or biennial mustard. The use of Indian mustard oil is discouraged in the International market due to its high erucic acid and glucosinolate content. It is being used in India past so many years and also has a niche in rich 
Indian culture. But its side effects have not been observed yet in India (Batra, 2003). Glucosinolate, the pungent principle in mustard oil, has anti-bacterial, anti-fungal and anticarcinogenic properties, which account for many medicinal utilities of the oil (Duke, 2008). It still has and will have a special place in future for cooking purpose in kitchens of North India. Soybean is a major source of high quality protein and Oil, and soybean seed quality is often determined by seed protein, oil, fatty acid, and mineral content. Therefore, improving soybean seed quality is key to improving human and animal nutrition (Bellaloui et al., 2010). The use of soybean products in the feed and food industry has increased steadily. The world soybean production is currently 219.8 million metric tons out of which India produced 9.3 million metric tons constituting about $4 \%$ of the total world production. Out of this production, less than $10 \%$ is directly used for human consumption (Gandhi, 2006). Sunflower oil is a high-quality edible oil. It is used in cooking, frying, and in the manufacture of margarine and shortening and considered by some as desirable as olive oil. Sunflower oil was selected in this study due to its high use in food as it is a rich source of linoleic acid. Furthermore, it is light in taste and appearance and has a toxic at low concentrations may be generated after destruction of the linoleic acid (Min and Boff, 2001). At high temperature and in the presence of air, many chemical reactions can be observed in oil: hydrolysis, polymerization, oxidation and isomerization (Rossell, 2001). The most common commercial products of groundnut are: groundnut oil, groundnut cake and fried peanuts which are sold at markets places or hawked on the streets (Hussaini et al., 2010; Salami, 2013). They are usually consumed after roasting or boiling, and also processed into different forms such as peanut butter, candy, chocolates, cakes, and others. Peanut butter and jelly sandwiches are popular in the American culture, with raw, roasted, shelled or unshelled forms of peanuts being available in United States throughout the year. Peanut oil is characterized by $45.2 \%$ oleic acid (18:1) and $32.4 \%$ linoleic acid (18:2), palmitic (C16:0), and a trace amount of linolenic fatty acid (C18:3), (Carrin and Carelli, 2010; Mzimbiri et al., 2014).

\section{Materials and methods}

All oils (Mustard oil, soybean oil, sun flower oil and Groundnut oil) were purchases from Shive Sales Corporation, 252, Kotla, Mayur Vihar Phase-1 Delhi- 110091 and packaging materials (PET Bottles) were purchases from local market of Meerut - 250110. Experiments were carried out to assessment of crude oil and blended oil in Process and Food Engineering Laboratory of the Department of Agricultural Engineering, Sardar Vallabhbhai Patel university of Agriculture and Technology, Modipuram, Meerut. Studies were also carried out to evaluate the physico-chemical property of crude and blended oil filled in PET bottle under different storage condition. The physico-chemical and sensory attributes were analysed just after preparation and during storage of 0 and 210 days under ambient condition packaging in pet bottle.

Density: The density of edible was calculated by mass of the sample per unit volume.

$$
\text { Density }=\frac{\text { mass of the oil }(\mathrm{g})}{\text { volume of the oil }\left(\mathrm{cm}^{3}\right)}
$$

Specific gravity: Specific gravity of oil is determined as the ratio of the density of oil in to the density of water at same temperature.

$$
\text { Specific gravity }=\frac{\text { Density of oil }}{\text { Density of water }}
$$

Peroxide value: Weight 2 gms of the oil sample a $25-\mathrm{ml}$ test tube. Add 2 gms of potassium iodide and $20 \mathrm{ml}$ of solvent mixture $\left(\mathrm{CH}_{3} \mathrm{COOH}\right.$ : $\left.\mathrm{CHCl}_{3}:: 2: 1\right)$. Loosely stopper test tube. Boil the contents of the tube within 30 seconds by placing the test tube in a boiling water bath. Boil for another 30 seconds. Cool the test tube immediately under tap water and transfer the contents of the tube into a conical flask. Add 20 
$\mathrm{ml}$ of $5 \%$ potassium iodide and $50 \mathrm{ml}$ of distilled water to the flask and titrate against $0.002 \mathrm{~N}$ sodium thiosulphate using starch indicator towards the end (Shukla, 2003).

Peroxide value $=\frac{\mathrm{V}}{\mathrm{W}}(\mathrm{ml}$ of $0.002 \mathrm{~N}$. Sodium thiosulphate per gm)

Where,

$$
\begin{aligned}
& \mathrm{V}=\mathrm{ml} \text { of } 0.002 \mathrm{~N} . \mathrm{Na}_{2} \mathrm{~S}_{2} \mathrm{O}_{3} \text { used. } \\
& \mathrm{W}=\text { weight of the sample taken in } \mathrm{g} .
\end{aligned}
$$

Free Fatty Acid (Acid Value): Weigh $10 \mathrm{~g}$ of oil or melted fat. Dissolve the sample in hot $100 \mathrm{ml}$ of neutralized ethanol and titrate using 0.01 or 0.1 $\mathrm{N}$ alkali using phenolphthalein as indicator. Shake vigorously during titration and keep the solution warm. When testing oils and fats which give dark coloured solution, use the indicators as stated under determination of saponification value (Ranganna, 2005).

\section{Acid value as oleic acid $=$} $\underline{\mathrm{ml} \text { of alkali } \times \mathrm{N} \text { of alkali } \times 56.1}$

wt of sample (g)

Iodine Value: The weight of to the sample required is $2.5-3.0 \mathrm{~g}$ in the case of coconut oil and 0.15 to $0.6 \mathrm{~g}$ in the case of other oils depending upon the iodine value. Weigh accurately by difference, an appropriate quantity of the oil or fat (previously melted) into a clean dry 250-ml glass-stoppered conical flask, and add $10 \mathrm{ml}$ of carbon tetrachloride. Add $25 \mathrm{ml}$ of Wijs solution, replace the stopper after moistening with potassium iodide solution, mix, and store in a dark cupboard for $30 \mathrm{~min}$ in the case of nondrying and semi-drying oils and $60 \mathrm{~min}$ in the case of drying oils. Add $15 \mathrm{ml}$ of $10 \%$ potassium iodide solution and $100 \mathrm{ml}$ of distilled water. Titrate with $0.1 \mathrm{~N} \mathrm{Na}_{2} \mathrm{~S}_{2} \mathrm{O}_{3}$ solution using starch as an indicator near the end point (Ranganna, 2005). Carry out a blank determination alongside without the fat.

$$
\begin{gathered}
\text { Iodine Value }= \\
\frac{(\text { Blank titre }- \text { Sample titre }) \times \mathrm{N} \text { of } \mathrm{Na} 2 \mathrm{~S} 2 \mathrm{O} 3}{\text { Wt of sample }(\mathrm{g})} \times 12.69
\end{gathered}
$$

Refractive Index: Refractive Index was determined using a mathematical expression derived by Perkins (1995).

$$
\mathrm{RI}=1.45765+0.0001164 \mathrm{IV}
$$

Where,

$\mathrm{RI}$ is the Refractive Index and IV is the Iodine Value

pH value: The digital $\mathrm{pH}$ meter is kept at stand by position firstly then calibrating the $\mathrm{pH} 7$ and pH 4 standard buffer solutions. The electrode of $\mathrm{pH}$ meter is dipped in test solution and the temperature knob is placed at $0^{\circ} \mathrm{C}$ control to the temperature of test solution. The function selector switch is set to $\mathrm{pH}$ and reading of digital display is allowed to stabilize, before it sample is mix or grind with $100 \mathrm{ml}$ water and filtered through what man filter paper No. 1. The filtered sample is used for $\mathrm{pH}$ measurement.

\section{Results and Discussion}

pH content: The $\mathrm{pH}$ data was found of individual oil ranged from 4.3 to 5.4. While in blended oil were 3.2 to 5.4 as fresh. The constant $\mathrm{pH}$ was observed 4.3 in $\mathrm{T}_{1}$ (mustard oil) \& highest 5.4 in $\mathrm{T}_{2}$ (Soybean oil) where as in case of blended oil, lowest was found in 4.2 in $\mathrm{T}_{8}$ $\left(\mathrm{MS}_{40}+\mathrm{SF}_{20}+\mathrm{GN}_{20}+\mathrm{SB}_{20}\right)$ and highest i.e. 4.5 in $\mathrm{T}_{5}$ Sample $\left(\mathrm{MS}_{85}+\mathrm{SB}_{5}+\mathrm{GN}_{5}+\mathrm{SF}_{5}\right)$. It is blended that the ratio of mustard oil affects the $\mathrm{pH}$ of fresh blended oil in different concentrations. As per data, the $\mathrm{pH}$ was observed highest in soybean oil. The present studs, the mustard oil used as based oil for replacement. The mustard oil was replaced with sunflower, soybean and groundnut combined in the ratio of 5, 10, 15 and $20 \%$ each blend oil of $\mathrm{T}_{5}$ single was observed highest than the other combination but lowest in $\mathrm{T}_{8}$ and followed by method in ascending affected by ratio of soybean oil (5 to $20 \%$ ), because the individually soybean has highest $\mathrm{pH}$ than the others. During the storage of individual and blended oil, $\mathrm{pH}$ was increase with increasing the storage period and types of storage condition. During room of oils, the $\mathrm{pH}$ was observed higher 
Ratnesh Kumar, Suresh Chandra, Samsher, Vikrant Kumar, Sunil and Pinkoo Singh

followed $\mathrm{BOD}\left(35^{\circ} \mathrm{C}\right)$ and refrigeration storage at 210 days. In refrigeration condition, $\mathrm{pH}$ was found highest for $\mathrm{T}_{5}$ and lowest $\mathrm{T}_{8}$; In BOD pH observed highest in $\mathrm{T}_{7}$ and lowest $\mathrm{T}_{5}$. In room storage $\mathrm{pH}$ was assessed highest $\mathrm{T}_{5}$ and lowest $\mathrm{T}_{8}$ during storage of 210 days. From the Fig. 1, it seems that the highest $\mathrm{pH}$ of blended oil $\left(\mathrm{T}_{5}\right)$ was observed in room storage and lowest 4.9 for $\mathrm{T}_{7} \&$ $\mathrm{T}_{5}$ in BOD $\left(35^{\circ} \mathrm{C}\right)$ temperature after 210 days of storage. The stagnant temperature of storage for 210 day can be affecting the $\mathrm{pH}$ of the fresh as well blended oil. The result of study also revealed that the $\mathrm{pH}$ increased up to $22.24 \%$ in refrigerator followed by $21.81 \%$ in room and lowest $31.51 \%$ in BOD in storage at 210 days.

Density: From the data it was found that density of individual oil ranged from 0.892 to 0.900 (Fig.-2). While in blended oil was observed from 0.894 to 0.897 . The density was reported that 0.892 in $T_{1}$ (mustard oil) \& highest in $T_{2}$ (Soybean oil) where as in case of blended oil, lowest was found in 0.894 in $\mathrm{T}_{5}$ $\left(\mathrm{MS}_{85}+\mathrm{SF}_{5}+\mathrm{GN}_{5}+\mathrm{SB}_{5}\right)$ and highest i.e. 0.897 in $\mathrm{T}_{8}$ Sample $\left(\mathrm{MS}_{40}+\mathrm{SB}_{20}+\mathrm{GN}_{20}+\mathrm{SF}_{20}\right)$. As per data, the density was observed highest in soybean oil compared to the mustard oil. It is blended oil that the ratio of mustard oil affects the fresh blended oil in different ratio. The mustard oil was replaced with sunflower, groundnut and soybean combined in the ratio of $5,10,15$ and $20 \%$. During the storage of individual and blended oil, density was reduced with raising the storage period and different storage condition, such as refrigeration, BOD and room. Room of oils, the density was reported higher followed refrigeration and $\mathrm{BOD}\left(35^{\circ} \mathrm{C}\right)$ at 210 days. In refrigeration storage, density was found highest for $\mathrm{T}_{8}$ and lowest $\mathrm{T}_{5}$; In BOD density was recorded highest in $\mathrm{T}_{5}$ and lowest $\mathrm{T}_{6}$; In room storage density was observed highest $\mathrm{T}_{8}$ and lowest $\mathrm{T}_{6}$ during storage of 210 days can be affected the density of fresh as well as blended oil.
Specific gravity: From the data it was found that specific gravity of individual oil ranged from 0.8363 to 0.8432 (Fig.-2). While in blended oil was observed from 0.8379 to 0.8410 . The specific gravity was reported that 0.8363 in $\mathrm{T}_{1}$ (mustard oil) \& highest in $\mathrm{T}_{2}$ (Soybean oil) where as in case of blended oil, lowest was found in 0.8379 in $\mathrm{T}_{7}\left(\mathrm{MS}_{55}+\mathrm{SF}_{15}+\mathrm{GN}_{15}+\mathrm{SB}_{15}\right)$ and highest i.e. 0.8410 in $\mathrm{T}_{8} \quad$ Sample $\left(\mathrm{MS}_{40}+\mathrm{SB}_{20}+\mathrm{GN}_{20}+\mathrm{SF}_{20}\right)$. As per data, the specific gravity was observed highest in soybean oil compared to the mustard oil. It is blended oil that the ratio of mustard oil affects the fresh blended oil in different ratio. The mustard oil was replaced with sunflower, groundnut and soybean combined in the ratio of 5, 10, 15 and $20 \%$. During the storage of individual and blended oil, specific gravity was reduced with raising the storage period and different storage condition, such as refrigeration, BOD and room. Room of oils, the specific gravity was reported higher followed refrigeration and $\mathrm{BOD}\left(35^{\circ} \mathrm{C}\right)$ at 210 days. In refrigeration storage, specific gravity was found highest for $\mathrm{T}_{8}$ and lowest $\mathrm{T}_{5}$; In BOD specific gravity was recorded highest in $\mathrm{T}_{5}$ and lowest $\mathrm{T}_{6}$; In room storage specific gravity was observed highest $\mathrm{T}_{8}$ and lowest $\mathrm{T}_{6}$ during storage of 210 days can be affected the specific gravity of fresh as well as blended oil.

Free fatty acid: The free fatty acid of individual oil ranged from 0.18 to 0.19 . While in blended oil were ranged from 0.14 to 0.19 as fresh. The constant free fatty acid was observed 0.18 in $\mathrm{T}_{2}$ (soybean oil) \& highest 0.19 in $\mathrm{T}_{1}$ (mustard oil) where as in case of blended oil, lowest was found 0.14 in $\mathrm{T}_{6}\left(\mathrm{MS}_{70}+\mathrm{SF}_{10}+\mathrm{GN}_{10}+\mathrm{SB}_{10}\right)$ and highest i.e. 0.19 in $\mathrm{T}_{5}$ Sample $\left(\mathrm{MS}_{85}+\mathrm{SF}_{5}+\mathrm{SB}_{5}+\mathrm{GN}_{5}\right)$. It is blended that the ratio of mustard oil affects the free fatty acid of fresh blended oil in different concentrations. As per data, the free fatty acid was observed highest in mustard oil. The present studs, the mustard oil used as based oil for replacement. The mustard oil was replaced with 
sunflower, groundnut and soybean combined in the ratio of 5, 10, 15 and $20 \%$, during the storage of individual and blended oil. Free fatty acid was increase with increasing the storage period and types of storage condition. During room of oils, the free fatty acid was observed higher followed refrigerator and $\mathrm{BOD}\left(35^{\circ} \mathrm{C}\right)$ storage at 210 days. In refrigeration condition, free fatty acid was found highest for $\mathrm{T}_{6}$ and lowest $\mathrm{T}_{8}$; In BOD free fatty acid observed highest in $\mathrm{T}_{5}$ and lowest $\mathrm{T}_{8}$; In room storage free fatty acid was assessed highest $T_{7}$ and lowest $T_{6}$ during storage of 210 days. From the Fig. 4, It seems that the highest free fatty acid of fresh oil $\left(\mathrm{T}_{4}\right)$ was observed in room storage and lowest 0.73 for $\mathrm{T}_{1} \& \mathrm{~T}_{3}$ in BOD temperature after 210 days of storage. The stagnant temperature of storage for 210 day can be affecting the free fatty acid of the fresh as well blended oil.

Iodine value: From the data it was found that iodine value of individual oil ranged from 2.20 to 2.22. The constant iodine value was recorded 2.20 in $\mathrm{T}_{4}$ (sunflower oil) \& highest 2.22 in $\mathrm{T}_{1}$ (mustard oil) where as in case of blended oil, lowest was found in 2.16 in $\mathrm{T}_{8}$ $\left(\mathrm{MS}_{40}+\mathrm{SF}_{20}+\mathrm{GN}_{20}+\mathrm{SB}_{20}\right)$ and highest i.e. 2.20 in $\mathrm{T}_{5}$ Sample $\left(\mathrm{MS}_{85}+\mathrm{SB}_{5}+\mathrm{GN}_{5}+\mathrm{SF}_{5}\right)$. It is blended that the ratio of mustard oil affects the iodine value of fresh blended oil in different concentrations. As per data, the iodine value was observed highest in mustard oil. The present studs, the mustard oil used as based oil for replacement. The mustard oil was replaced with sunflower, soybean and groundnut combined in the ratio of 5, 10, 15 and 20\%. During the storage of individual and blended oil, iodine value was decrease with increasing the storage period and types of storage condition. During room of oils, the iodine value was observed higher followed BOD $\left(35^{\circ} \mathrm{C}\right)$ and refrigeration storage at 210 days. In refrigeration condition, iodine value was found highest for $\mathrm{T}_{7}$ and lowest $\mathrm{T}_{5}$; In BOD iodine value observed highest in $\mathrm{T}_{8}$ and lowest $\mathrm{T}_{5}$ ; In room storage iodine value was assessed highest $\mathrm{T}_{6}$ and lowest $\mathrm{T}_{5}$ during storage of 210 days. From the Fig. 5, It seems that the highest iodine value of blended oil $\left(\mathrm{T}_{6}\right)$ was observed in room storage and lowest 1.27 for $\mathrm{T}_{8} \& \mathrm{~T}_{5}$ in $\mathrm{BOD}$ temperature after 210 days of storage. The stagnant temperature of storage for 210 day can be affecting the iodine value of the fresh as well blended oil.

Peroxide value: The peroxide value of individual oil ranged from 0.16 to 0.34 . While in blended oil were 0.26 to 0.29 as fresh. The constant peroxide value was observed 0.16 in $\mathrm{T}_{3}$ (sunflower oil) \& highest 0.34 in $\mathrm{T}_{1}$ (mustard oil) where as in case of blended oil, lowest was found in 0.26 in $\mathrm{T}_{8}$ $\left(\mathrm{MS}_{40}+\mathrm{SB}_{20}+\mathrm{SF}_{20}+\mathrm{GN}_{20}\right)$ and highest i.e. 0.29 in $\mathrm{T}_{5}$ Sample $\left(\mathrm{MS}_{85}+\mathrm{SF}_{5}+\mathrm{GN}_{5}+\mathrm{SB}_{5}\right)$. It is blended that the ratio of mustard oil affects the peroxide value of fresh blended oil in different concentrations. As per data, the peroxide was observed highest in mustard oil. The present studs, the mustard oil used as based oil for replacement. The mustard oil was replaced with sunflower, soybean and groundnut combined in the ratio of 5, 10, 15 and 20\%. During the storage of individual and blended oil, peroxide value was increased with increasing the storage period and types of storage condition. During refrigeration of oils, the peroxide value was observed higher followed room and BOD $\left(35^{\circ} \mathrm{C}\right)$ storage at 210 days. In refrigeration condition, the peroxide value of blended oil highest $\mathrm{T}_{6}$ and lowest $\mathrm{T}_{8}$; In BOD peroxide value recorded highest in $T_{5}$ and lowest $\mathrm{T}_{8}$; In room storage peroxide value was assessed highest $\mathrm{T}_{5}$ and lowest $\mathrm{T}_{8}$ during storage of 210 days. From the Fig. 6, It seems that the highest $\mathrm{pH}$ of blended oil $\left(\mathrm{T}_{5}\right)$ was observed in room storage and lowest 0.90 for $\mathrm{T}_{5} \& \mathrm{~T}_{8}$ in BOD $\left(35^{\circ} \mathrm{C}\right)$ temperature after 210 days of storage. The stagnant temperature of storage for 210 day can be affecting the peroxide value of the fresh as well blended oil. 


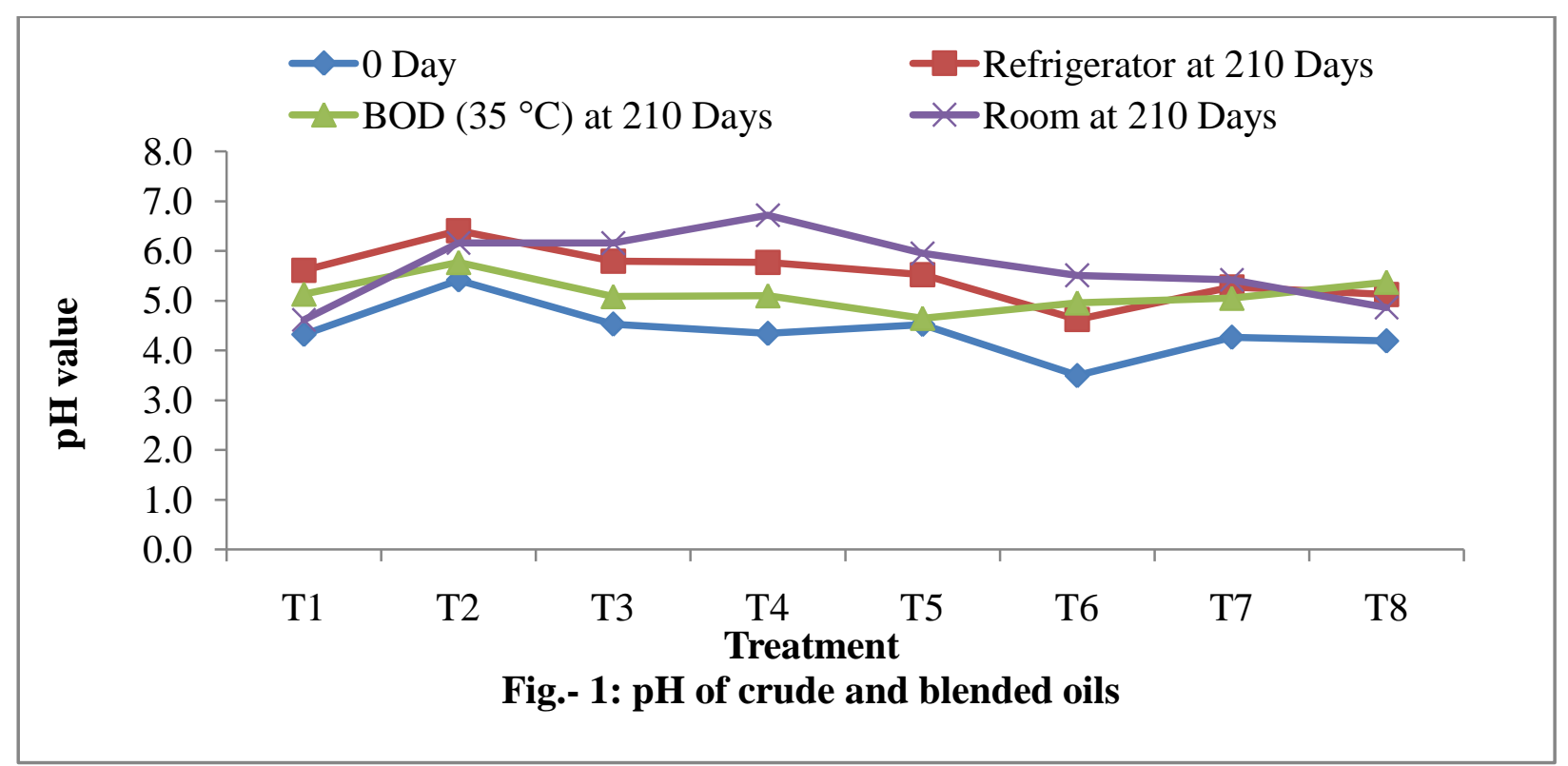

Description :- $\left(\mathrm{T}_{1}\right)$ - MS: Mustard oil, $\left(\mathrm{T}_{2}\right)$ - SB: Soybean oil, $\left(\mathrm{T}_{3}\right)$ - SF: Sunflower oil, $\left(\mathrm{T}_{4}\right)$ - GN: Groundnut oil, $\left(\mathrm{T}_{5}\right)$ $\mathrm{MS}(85 \%)+\mathrm{SB}(5 \%)+\mathrm{SF}(5 \%)+\mathrm{GN}(5 \%),\left(\mathrm{T}_{6}\right)-\mathrm{MS}(70 \%)+\mathrm{SB}(10 \%)+\mathrm{SF}(10 \%)+\mathrm{GN}(10 \%),\left(\mathrm{T}_{7}\right)-\mathrm{MS}(55 \%)+\mathrm{SB}(15 \%)+$ $\mathrm{SF}(15 \%)+\mathrm{GN}(15 \%)\left(\mathrm{T}_{8}\right)-\mathrm{MS}(40 \%)+\mathrm{SB}(20 \%)+\mathrm{SF}(20 \%)+\mathrm{GN}(20 \%)$.

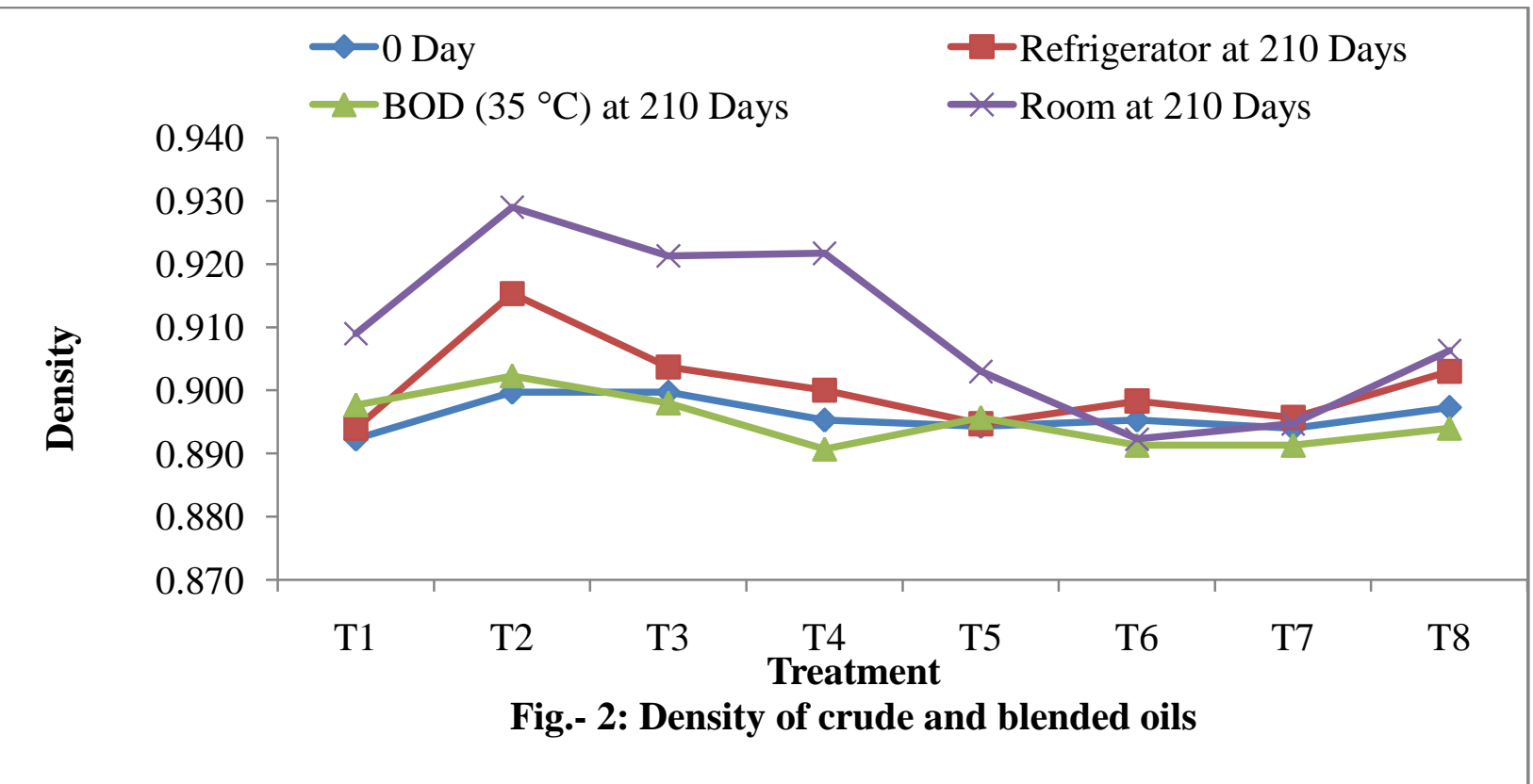



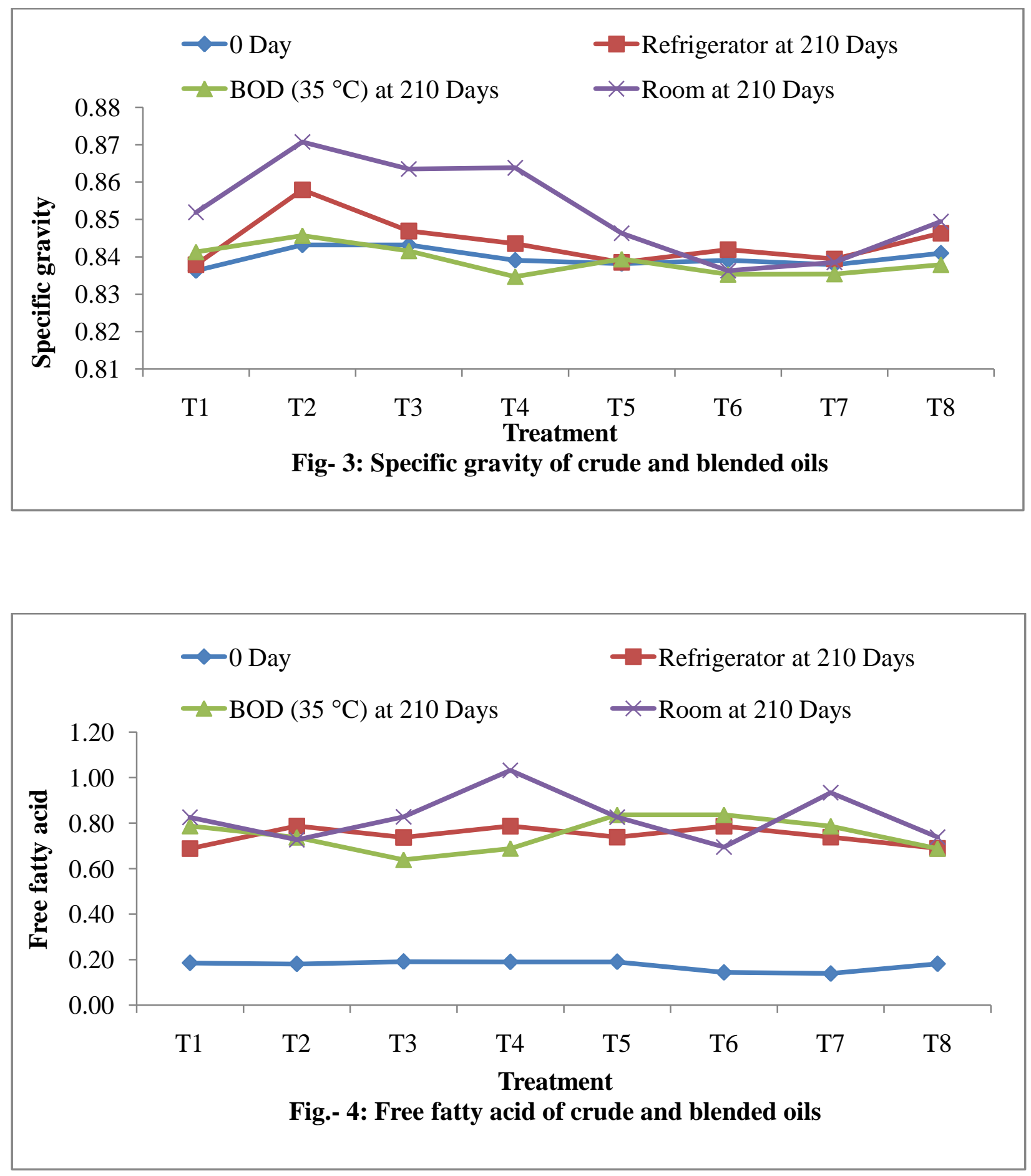

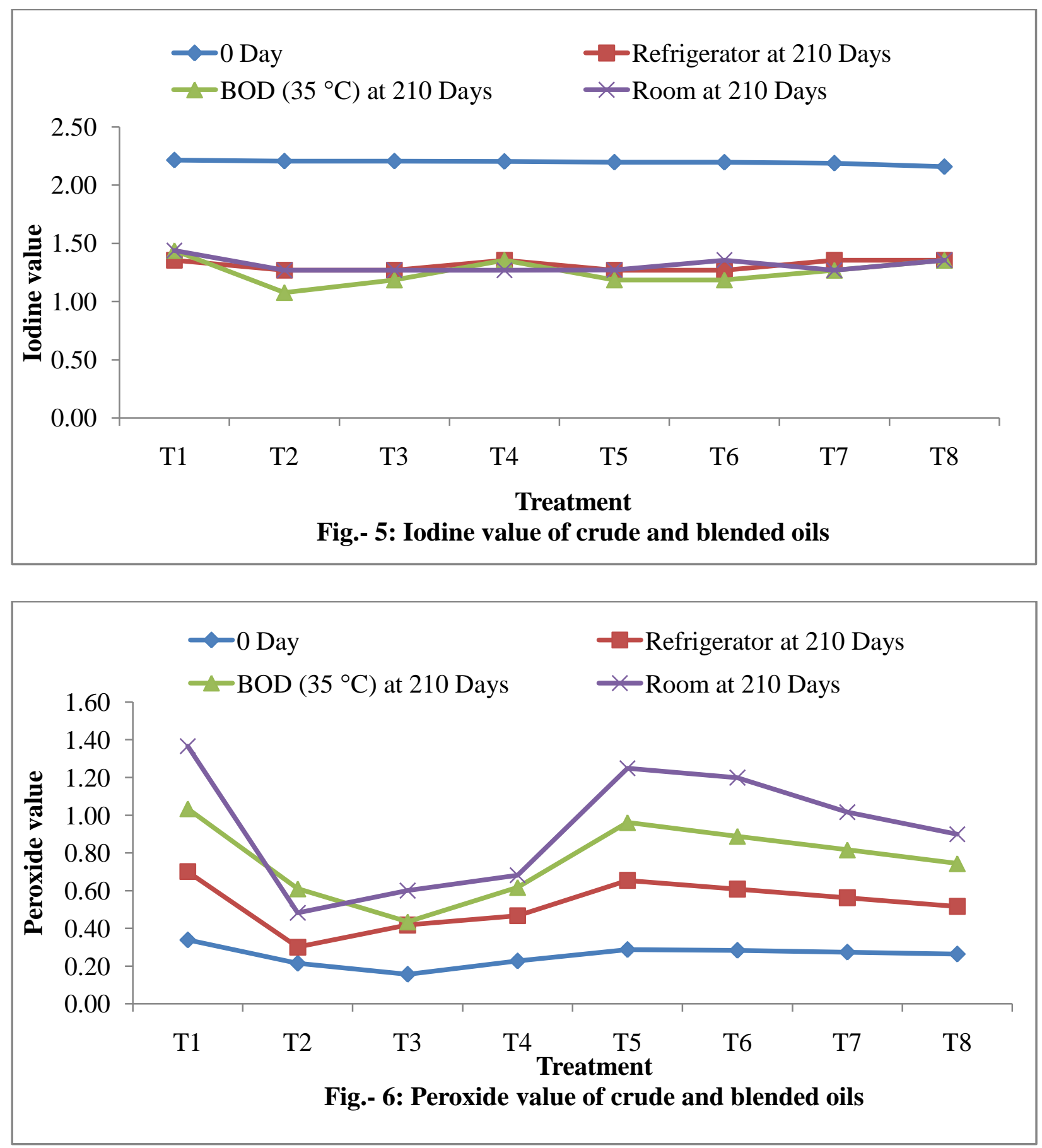

\section{Conclusions}

The experimental results show that $\mathrm{pH}$ was increase with increasing the storage period and types of storage condition. As per data, the density was observed highest in soybean oil compared to the mustard oil. During the storage of individual and blended oil, specific gravity was reduced with raising the storage period and different storage condition, such as refrigeration, BOD and room. During the storage of individual and blended oil, free fatty acid was increase with increasing the storage period and types of 
storage condition. During room of oils, the free fatty acid was observed higher followed refrigerator and $\mathrm{BOD}\left(35^{\circ} \mathrm{C}\right)$ storage at 210 days. During the storage of individual and blended oil, iodine value was decrease with increasing the storage period and types of storage condition. During refrigeration of oils, the peroxide value was observed higher followed room and $\mathrm{BOD}\left(35^{\circ} \mathrm{C}\right)$ storage at 210 days.

\section{Acknowledgements}

This work was supported by the department of Agricultural Engineering laboratory in Sardar Vallbhbhai Patel University of Agriculture and Technology, Meerut, Uttar Pradesh, INDIAN, under the thesis work of Post Graduate Studies in 2018.

\section{References}

Batra, P. (2003). Evaluation Of Mustard Oil As A Health Oil In Rat Model,Department of Medical Elementology and Toxicology,Faculty of Science.

Bellaloui, N., Bellaloui, H.A., Gillen, A.M., Abbas, H.K., Zablotowicz, R.M., Mengistu, A. and Paris, R.L. (2010). Soybean seed protein, oil, fatty acids, and mineral composition as influenced by soybean-corn rotation. Agricultural Sciences, 1(3):102-109.

Carrin, M.E. and Carelli, A.A. (2010). Peanut Oil Composition data. European Journal of Lipid Science and Technology. Vol 112, Issue 7, Pages 693-818. Wiley Online Library. KGaA, Weinheim.

Dasgupta, S. and Bhattacharyya, D.K. (2007). Dietary effect of gamma-linolenic acid on the lipid profile of rat fed erucic acid rich oil. J. Oleo. Sci., 56: 569-577.

Duke, J.A., (2008). Duke's Handbook of Medicinal Plants of the Bible. CRC Press, Boca Raton, ISBN-13: 978-0-8493-82024, pp.: 65-69.
Gandhi, A. P. (2006). Soybean-the greater bean, World Grain (USA), February issue, p 5962.

Hussaini, Y.I., Napoleon, D.S. and Hassan, I.I. (2010). An Evaluation of Groundnut Processing by Women in a Rural Area of North Central Nigeria. Journal of Agricultural Science, 2 (1):206-210.

Min, D.B. and Boff, J.F. (2001). Lipid oxidation of edible oil. In C. Akoh and D. B . Min edn. Food lipids. New York, Marcel Dekker. pp. 335-363.

Mzimbiri, R., Shi, A.M., Liu, H. and Wang, Q. (2014). A Review: Peanut Fatty Acids Determination Using Hyper Spectroscopy Imaging and Its Significance on Food Quality and Safety. Food Science and Quality Management, 28:90-97.

Perkins, G. (1995). Physical properties of soybeans, in Erickson (Ed.), Practical handbook of soybean processing and utilization, 3 (Champaign, IL: AOCS Press) 29-38.

Ranganna, S. (2005). Handbook of analysis and quality control for fruit and vegetable products. Tata Mc Graw- Hill Publishing Company Limited, New Delhi.

Rastogi, T., Reddy, K.S., Vaz, M., Spiegelman, D. and Prabhakaran, D., Willett, W.C. and Ascheri, A. (2004). Diet and risk of ischemic heart disease in India1-3. Am. J. Clin. Nutr., 79: 582-592.

Rossell, J.B. (2001). Frying. Improving quality. In J. B. Rossell edn. Cambridge England. Woodhead Publishing Limited.

Salami, A.O. (2013). Heuristic Approach to Job Scheduling in a Small Scale Groundnut Oil Processing Firm in Nigeria. European Journal of Business and Management, 15(18):25-34.

Shukla, B.D., Srivastava, P.K. and Gupta, R.K. (1992). Oil seed Processing Technology, CIAE Bhopal (India). 
Shukla, S.G. (2003). Dairy Chemistry. Aman Publishing House Madhu Market, Naveen Bazar, Meerut (UP).

Stamer, D.E., Hamama, A.A. and Bhardwaj, L. (1999). Canola oil yield and quality as affected by production practices in Virginia, In: Janick J., (ed.) Perspectives on new crops and new uses, ASHS Press, Alexandria, VA. pp. 254-256.

$\begin{array}{ll}\text { Received } & : \text { September, 2019 } \\ \text { Revised } & : \text { October, 2019 } \\ \text { Published } & : \text { December, 2019 }\end{array}$

